\section{Stolz and M. Tamm}

Clinic of Pneumology, University Hospital Basel, Basel, Switzerland.

\section{STATEMENT OF INTEREST}

A statement of interest for D. Stolz can be found at www.erj.ersjournals.com/misc/statements.shtml

\section{REFERENCES}

1 Stolz D, Rasch H, Linka A, et al. A randomised, controlled trial of bosentan in severe COPD. Eur Respir J 2008; 32: 619-628.

2 Humbert M, Sitbon O, Simonneau G. Treatment of pulmonary arterial hypertension. N Engl J Med 2004; 351: 1425-1436.

3 Rietema H, Holverda S, Bogaard HJ, et al. Sildenafil treatment in COPD does not affect stroke volume or exercise capacity. Eur Respir J 2008; 31: 759-764.

4 Cook DI, Gebski VJ, Keech AC. Subgroup analysis in clinical trials. Med J Aust 2004; 180: 289-291.

5 Higenbottam T. Pulmonary hypertension and chronic obstructive pulmonary disease: a case for treatment. Proc Am Thorac Soc 2005; 2: 12-19.

6 Santos S, Peinado VI, Ramirez J, et al. Characterisation of pulmonary vascular remodelling in smokers and patients with mild COPD. Eur Respir J 2002; 19: 632-638.

7 Hale KA, Niewoehner DE, Cosio MG. Morphologic changes in the muscular pulmonary arteries: relationship to cigarette smoking, airway disease, and emphysema. Am Rev Respir Dis 1980; 122: 273-278.

8 Tithof PK, Elgayyar M, Cho Y, Guan W, Fisher AB, PetersGolden M. Polycyclic aromatic hydrocarbons present in cigarette smoke cause endothelial cell apoptosis by a phospholipase A2-dependent mechanism. FASEB J 2002; 16: 1463-1464.

9 Sekhon HS, Wright JL, Churg A. Cigarette smoke causes rapid cell proliferation in small airways and associated pulmonary arteries. Am J Physiol 1994; 267: L557-L563.

10 Cracowski JL, Cracowski C, Bessard G, et al. Increased lipid peroxidation in patients with pulmonary hypertension. Am J Respir Crit Care Med 2001; 164: 1038-1042.

11 Barbera JA, Peinado VI, Santos S, Ramirez J, Roca J, Rodriguez-Roisin R. Reduced expression of endothelial nitric oxide synthase in pulmonary arteries of smokers. Am J Respir Crit Care Med 2001; 164: 709-713.

12 Davie N, Haleen SJ, Upton PD, et al. ET(A) and ET(B) receptors modulate the proliferation of human pulmonary artery smooth muscle cells. Am J Respir Crit Care Med 2002; 165: 398-405.

13 Kuc RE, Davenport AP. Endothelin-A-receptors in human aorta and pulmonary arteries are downregulated in patients with cardiovascular disease: an adaptive response to increased levels of endothelin-1? J Cardiovasc Pharmacol 2000;36, 5: Suppl. 1, S377-S379.

14 Stolz D, Christ-Crain M, Morgenthaler NG, et al. Plasma pro-adrenomedullin but not plasma pro-endothelin predicts survival in exacerbations of COPD. Chest 2008; 134: 263-272.

15 Alp S, Skrygan M, Schmidt WE, Bastian A. Sildenafil improves hemodynamic parameters in COPD - an investigation of six patients. Pulm Pharmacol Ther 2006; 19: 386-390.

16 King TE Jr, Behr J, Brown KK, et al. BUILD-1: a randomized placebo-controlled trial of bosentan in idiopathic pulmonary fibrosis. Am J Respir Crit Care Med 2008; 177: 75-81.

\title{
Regional variations in pulmonary endarterectomy rates within the UK
}

\section{To the Editors:}

We were very interested in the paper by TOSHNER et al. [1] which highlights regional variations in pulmonary endarterectomy (PEA) rates for the UK population. The authors explore the reasons for this variability. Understandably they dismiss the possibility of differences due to variability in incidence or management. Their analysis looks at the PEA rate rather than the referral rate. This reduces, but does not abolish, the varying threshold for referral by designated centres as a cause. However, they conclude that the differences shown in the paper, are in a large part, due to the distance of patients from nationally designated centres for the management of pulmonary hypertension.

The one region that does not fit with this explanation is Scotland (UK) where there is a national centre for the management of pulmonary hypertension (the Scottish Pulmonary Vascular Unit (SPVU), Glasgow, UK) but the PEA rate appears to be similar to that seen in regions not served by pulmonary hypertension centres. In order to understand the reasons for the Scottish results, we have analysed the data on chronic thromboembolic pulmonary hypertension (CTEPH) patients seen by the SPVU between 2000 and 2008 (table 1).

These data show a number of possible additional reasons for the low Scottish rate seen in the TosHNER et al. [1] study. The first is that the period 2000-2006 was early in the existence of the SPVU when its referral base was building rapidly. PEA incidence in our patients has increased dramatically over the last 8 yrs leading to a three-fold increase in the number of patients with CTEPH referred to our unit between the two epochs analysed in table 1 . This occurred in parallel with an 


\begin{tabular}{|c|c|c|c|c|}
\hline \multirow[t]{2}{*}{ TABLE 1} & \multicolumn{4}{|c|}{$\begin{array}{l}\text { Outcome of cases with chronic thromboembolic pulmonary hypertension diagnosed by the Scottish Pulmonary } \\
\text { Vascular Unit between } 2000 \text { and } 2008\end{array}$} \\
\hline & & Aug 2000 - July 2004 & Aug 2004 - July 2008 & $\begin{array}{l}\text { Annual rate per million } \\
\text { for 2004-2008 }\end{array}$ \\
\hline \multicolumn{2}{|c|}{ Cases diagnosed } & 18 & 50 & 2.5 \\
\hline \multicolumn{2}{|c|}{ Cases referred to Papworth } & 16 & 44 & 2.2 \\
\hline \multicolumn{5}{|c|}{ Patients referred to Papworth } \\
\hline \multicolumn{2}{|l|}{ Operable } & 8 & 26 & 1.3 \\
\hline \multicolumn{2}{|c|}{ Not operable } & 7 & 13 & \\
\hline \multicolumn{2}{|c|}{ Awaiting decision } & 0 & 4 & \\
\hline \multicolumn{2}{|c|}{ Died before being seen } & 1 & 1 & \\
\hline \multicolumn{5}{|c|}{ Outcome if operable } \\
\hline
\end{tabular}

Data are presented as n. PEA: pulmonary endarterectomy. These data show a number of possible additional reasons for the low Scottish rate seen in the study by Toshner et al. [1]

increase in referral rate to the SPVU of all forms of pulmonary hypertension, which doubled between 2003 and 2007. We do not know if the data for the English units show a similar activity trend. For the period 2004-2008, the annual Scottish PEA rate was 1.0 case $\cdot \mathrm{million}^{-1} \cdot \mathrm{yr}^{-1}$. This is much closer to the average East of England rate for 2000-2006 (1.27 cases $\cdot$ million $^{-1}$. $\mathrm{yr}^{-1}$ ) than the figure calculated by TOSHNER et al. [1] for Scotland for 2000-2006 (0.57 cases $\cdot$ million $\left.^{-1} \cdot \mathrm{yr}^{-1}\right)$.

Secondly, the incidence of operable patients in Scotland between 2004 to 2008 was 1.3 cases $\cdot$ million $^{-1} \cdot \mathrm{yr}^{-1}$ (cf. the PEA rate for East of England patients 1.27 cases $\left.\cdot \mathrm{million}^{-1} \cdot \mathrm{yr}^{-1}\right)$. However, five (19\%) of the Scottish CTEPH patients who were deemed operable declined surgery. This compares with $9 \%$ of patients who declined surgery in the UK as a whole [2]. In four out of five of these cases, the patients had mild disease and did not consider the risk-b'enefit ratio of surgery to be in their interest. The fifth patient did have more severe disease but was aged $81 \mathrm{yrs}$ and both distance and risks of surgery were deterrent factors. We do not know the proportion of operable patients who proceed to surgery for the other UK regions. It may be that this is lower in Scottish patients because of the greater distances involved or different interpretation of the risks of surgery.

Thirdly, it is the policy of our unit to refer all patients diagnosed with CTEPH to Papworth Hospital (Cambridge, UK) for their opinion on operability. Despite that policy, this opinion was not obtained in eight $(12 \%)$ of our cases. We have reviewed these cases locally since the publication of the study by Toshner et al. [1] and are confident that these do not represent any missed operable cases.

In conclusion, current data from the Scottish Pulmonary Vascular Unit are closer to that seen in UK areas with nationally designated centres than estimated in the study by TOSHNER et al. [1] and add support to the conclusion that all such centres promote increased referral rates for pulmonary endarterectomy. Analysis of incidence of technically operable cases rather than pulmonary endarterectomys performed might give a more accurate comparison between regions.

\section{M.K. Johnson, W.N. Lee, M.W. Sproule and A.J. Peacock}

Scottish Pulmonary Vascular Unit, Golden Jubilee National Hospital, Glasgow, UK.

\section{STATEMENT OF INTEREST}

A statement of interest for A.J. Peacock can be found at www.erj.ersjournals.com/misc/statements.shtml

\section{REFERENCES}

1 Toshner M, Suntharalingam J, Goldsmith K, et al. Current differences in referral patterns for pulmonary endarterectomy in the UK. Eur Respir J 2008; 32: 660-663.

2 Condliffe R, Kiely DG, Gibbs JSR, et al. Improved outcomes in medically and surgically treated chronic thromboembolic pulmonary hypertension. Am J Respir Crit Care Med 2008; 177: 1122-1127.

DOI: $10.1183 / 09031936.00147608$

\section{From the authors:}

We thank M.K. Johnston and co-workers for their further work on national referral rates of patients with chronic thromboembolic pulmonary hypertension (CTEPH) in the UK. In our original paper [1], we offered the relative lack of specialist centres over a large geographical area as an explanation for the lower referral rates in Scotland. We find their further analysis of Scottish referral patterns to be a useful addition and note 